\title{
Rethinking the Continuum between Public and Private Actors in Electricity Policy in the Context of the UK Energy Transition*
}

\author{
LUCIE DE CARVALHO** \\ Department of Anglophone Studies, Université de Lille
}

\begin{abstract}
At the turn of the 1990s, a very large part of UK energy utilities was transferred from the public sector into private ownership. When analysing the era of privatisation, recent research on public policy has concluded that public authorities' ability to influence or shape national energy choices has been substantially weakened. Since the mid-2000s, however, tight cooperation between private investors and UK public regulators and policy-makers has emerged as a critical factor to meet the challenges posed by the energy transition. How have the British public authorities tried to get private actors on board and to involve them not only in the delivery and funding of energy services, as has been the case with public-private partnerships, but also in the decision-making process? This article identifies various schemes spearheaded by the UK government to breed or revive innovation in the privately-owned renewable and nuclear energy industries. This analysis explores the various strategies used to facilitate 'decompartmentalising' initiatives and ensure a smooth transition towards a neo-corporatist revival of the Triple Helix involving industry, academia, and government. It shows how these hybrid processes offer valuable insight for analysing and reconceptualising the boundary between the public and the private sectors. Based on this case study, this analysis ultimately demonstrates how the public/private dichotomy should be reassessed using the concepts of hybrid roles and responsibilities.
\end{abstract}

Keywords: private actors, multi-actor transition, energy transition, governance Sociologický časopis/Czech Sociological Review, 2018, Vol. 54, No. 6: 881-906

https://doi.org/10.13060/00380288.2018.54.6.434

\section{Introduction}

Since the end of the 1990s, a growing consensus has emerged on the need to rethink modern energy systems to adapt them to the new imperative of environmental sustainability [Steward 2013]. Several scenarios on future energy systems

\footnotetext{
* I wish to thank the two reviewers for their critical reading and suggestions. They provided many very valuable and helpful comments to improve and clarify this manuscript. ** Direct all correspondence Lucie de Carvalho, Department of Anglophone Studies, Université de Lille: e-mail: lucie.de-carvalho@univ-lille.fr.
}

(C) Sociologický ústav AV ČR, v.v.i., Praha 2018 
have compared this change to the structural paradigm shift of the early 20th century, which had turned fossil fuels into the foundation of the world economy [Helm 2005, 2007]. In the face of growing energy needs, dwindling natural resources, and more stringent calls to mitigate climate change, there have been numerous demands to transition towards low-carbon energy mixes that would nonetheless be compliant with steady economic growth [Richmond and Kaufman 2006; Hannesson 2009]. As the socio-technical transition literature has highlighted, paradigmatic transitions are essentially based on 'multi-actor processes' [Grin et al. 2010: 11], which fundamentally alter socio-technical systems by triggering 'far-reaching changes along different directions: technical, material, organizational, institutional, political, economic and socio-cultural' [Markard, Raven and Truffer 2012: 956].

In practice, a paradigmatic energy transition involves 'changing practices by the full range of actors in the energy system, ranging from electricity suppliers to wholesalers, supply companies, network operators, energy service providers and users of energy', through the introduction of appropriate, long-term, and efficient incentives from central authorities [Lockwood et al. 2013: 6]. These incentives aim to prompt an enduring overhaul of technological resources, market practices and economic regulation [Geels 2004, 2010; Rip and Kemp 1998; Rotmans, Kemp and Van Asselt 2001]. In 2007, the White Paper 'Meeting the Energy Challenge' took the UK down the road of energy transition, as the government embraced an energy mix based on nuclear and renewable energy, in order to meet both UK and EU low-carbon emission targets [DTI 2007: 13].

Yet, considering its outdated nuclear sector and budding renewable market, spurring this structural shift in electricity production has proved a daunting task for the UK government and revealed two major challenges. Firstly, this agenda has tested the country's ability to innovate and its industrial capacity to meet the new demands in terms of R\&D, supply and workforce-three industrial facets that stand at the confluence of three actors: academia, private suppliers and operators, and government. Secondly, other obstacles have also surfaced when attempting to introduce long-term 'far-reaching changes'. Indeed, the UK electricity sector was virtually fully privatised in the late 1980s, which not only embedded market-based ideas of profitability and competitiveness in the electricity sector, but also clearly divided labour and responsibilities between public bodies such as regulators, and private actors as service providers in a more horizontal fashion [Moran 2003].

In fact, these impeding parameters are symptomatic of two major dynamics at play as identified by the extensive body of literature on governance that has appeared since the late 1990s [Rhodes 1997]. Firstly, state leverage and bargaining power have waned to the benefit of private actors. Secondly, private actors' involvement in policy-making and implementation has also grown through the expansion of public-private partnerships (PPPs) in public services. As the transition literature has underlined, however, efficient cooperation between private investors and public regulators and decision-makers is thus essential to meet the 
innovation challenge and bridge the energy gap. However, the Brown government (2007-2010) reiterated their commitment to limiting state investments to a bare minimum and leaving the private sector in charge of seizing the business opportunities created by the energy transition.

Such a restricted involvement has therefore emerged as a potentially key problem due to the systemic dislocation between private interests and public objectives. Many issues have stemmed from frequent incompatibilities between the short-term and profitability-led investment objectives of the private sector and the more long-term, efficiency-based and sustainable demands of energy services. In the wake of the deregulation of the UK energy sector, the former have prevailed over the latter and in this case, complete private control has proved unsatisfactory for public service providers. Between 2007 and 2009, the nuclear renaissance almost ended in a gridlock and renewables were slow to pick up following the government's guidelines, as private actors proved reluctant to shoulder the financial weight and risks associated with the transition.

Consequently, all these questions related to responsibility sharing and the sheer capabilities of both the private and public sector offer a valuable departure point for the discussion of the changing nature of the key actors involved in the process. In other words, analysing the energy transition in Britain allows us to engage in an epistemological discussion of the private/public dichotomy. The purpose of this paper is to take a sector-specific approach and consider the UK energy challenge as an empirical basis from which to explore how the various sets of actors have been interfacing with each other to address these new demands, and conceptualise actors' agency and interactions, through the analytical lens of the public-private nexus. The realities of the interactions between private and public sectors, but also the very semantics attached to these twin concepts must be considered. While fairly simple in meaning, the terms public and private still remain difficult to fathom. It is thus first necessary to present their most common definitions.

Historically speaking, private and public have been thought of as two distinct and separate items, to be apprehended in relative terms, which help provide a conceptual framework to modern societies. The private world as both an object and a notion has traditionally been presented as the negative facet of the public world in terms of not only structure and workings, but also values and norms [Habermas 1962]. From the first explosion of interest in the dichotomy between public and private, researchers and contributors immediately underscored the very diverse understanding of this conceptual distinction used in a very wide range of research fields. Yet, as early as 1988, Perry and Rayney underlined how potentially artificial and difficult to grasp this dichotomy was, as 'the blurring of the public and private sectors in most countries shows that the concepts are multidimensional, and this in turn complicates the definition' [1988: 183]. They highlight that this dichotomy, however useful, nonetheless raises questions as regards the parameters to be considered to determine the limit between these two spheres. 
In political economy and sociology, extensive literature has most commonly framed this concept of boundary in economic terms. The definition inherited from Western liberal discourses contends that the components of these two 'sectors' need to be distinguished according to funding and ownership arrangements. In that sense, the private sector has come to be characterised by a 'market-based' structure, their activities as 'private or vested interests' or 'lobbies,' or their basic industrial function, such as 'contractors' or 'investors'. In other words, the economic lexicon and lens through which the public vs private dichotomy is commonly viewed tends to associate with 'public' concepts such as 'public interest', 'regulation,' 'institutional and political' and 'public funding', and with 'private', qualifiers such as 'business', 'market', and 'profit-making.' Such a distinction was further entrenched with the partial or complete privatisation of formerly public sectors in capitalist societies throughout the 1980s-1990s.

Although it has always been assumed that the boundary between these two spheres was intrinsically flexible and permeable, many scholars have suggested that this structural binary opposition along economic lines has failed to encompass the sheer complexity of their nature [Stark 2010: 5]. Weintraub famously contended that "any notion of "public" or "private" makes sense only as one element in a paired opposition', and that such a dichotomous model is 'likely to be inherently misleading, because the procrustean dualism of their categories will tend to blank out important phenomena' [1997: 13-15].

Yet, despite these identified shortcomings, this binary approach is still used as a conceptual tool to map out the various sets of actors involved in modern governance. They somehow fall short of reflecting the sheer complexity of the way the various stakeholders engage in policy-making when dealing with such largescale paradigmatic challenges. It often emerges that existing pragmatic policy arrangements are artificially constrained within these existing, albeit imperfect, conceptual boxes.

The idea is therefore to offer an alternative approach to the geography of actors through two avenues. Firstly, one option could be to develop a more holistic view not of a clear boundary between private and public but of a continuum where public and private actors' interests converge, align, and merge. The second approach to overcome this deadlock is to reconsider the defining parameters distinguishing private from public. As Moran underlined, privatisation strongly impacted this dichotomy-clearly separating the two spheres of intervention along two distinct lines of funding and authority. It can therefore be argued that preserving this basic 'compartimentalisation' along ownership and funding lines that leads to defining 'the public sector as synonymous with government, thus leaving all else to be subsumed under the private sector' [Cooper 1985: 103] has become limiting and simplistic. It follows that approaching the private sector as having 'vested interests', intrinsically geared towards short-term and profitmaking objectives, is similarly inadequate. Questioning this polarity of 'public v. vested/sectorial interests' may help to add nuance to the traditional adversarial 
and teleological approach which has tended to mount public and private interests as intrinsically opposite in nature and objectives.

The idea is thus to follow an expanding body of empirical literature on the boundary dynamics between public and private entities in political affairs, understanding the two as a 'private-public policy nexus' [Stone 2013]. This recent literature has been fruitful in defining participants and their modes of interaction, particularly in the regulation arena. Mosley underscored how interdependent the private sector or 'non-state' actors had become in jointly acting on financial regulation for the public good [2009], whilst others refer to new 'patterns of interplay between public and private' [Verbruggen and Havinga 2015], 'a new constellation of actors' [Van de Donk 2008: 89]; or to private actors as 'sentinels' in particular areas of regulation, namely the fight against money-laundering in the banking industry [Favarel-Garrigues, Godefroy and Lascoumes 2007]. These analyses suggest that approaching private bodies as actors engaging in active interactions with what is traditionally defined as the public bodies may help further the definition of both.

This method of conceptualising actors in relation to their roles and interactions (agency) aptly interlocks with a new body of empirical sociological research on sustainable transition [Fischer and Newig 2016; Wittmayer et al. 2017]. These analyses consider power relations and collective actors in terms of their original roles and resources, still identifying, for instance, policymakers and public authorities as distinct from markets and businesses [Farla et al. 2012]. We will thus draw on their definition of roles as activities, but also on resources and boundary objects [Wittmayer et al. 2017]. Our aim is therefore to use Wittmayer's 'roles' and objectives as tools to analyse the links between private actors and policymakers since 'a change in role understandings can indicate changing interactions and relations between actors' [2017: 46].

This paper contributes to the body of knowledge about governance and the interactions between actors in order to go beyond the public-private binary approach and to view their interactions not through the prism of their nature or origin but through their roles in policy-making. This analysis covers the early stages of the energy transition, and will first identify the capability issues triggered by the liberalisation of the UK electricity sector. It then focuses on the anticipatory measures introduced upstream to buttress the UK R\&D, skills and supply capabilities under the Brown and coalition governments. Finally, it explores some of the schemes implemented to rejuvenate, foster, or strengthen collaboration and partnerships with the private sector, thus reshaping the borderline between the traditionally-distinct private and public sectors in a more synergetic fashion. Ultimately, this paper aims to demonstrate how the context of energy transition has forced public and private stakeholders to become joint architects of Britain's current energy policy, thus deactivating the public-private binary structure. 


\section{Consequences of liberalisation and de-regulation on the industrial capacity of the British electricity sector}

\section{Transition era: identifying the capability and innovation gaps in Britain}

In 2007, the country officially opted for a hybrid strategy of encouraging both renewable electricity production-mostly wind and solar power-and nuclear power generation. Yet, despite Britain's involvement in sustainability policies through EU and domestic frameworks, many commentators agree that the country has been slow to jump on the bandwagon of energy transition through the expansion of low-carbon energy sources [Lockwood et al. 2013; Thomas 2004; Verbong and Loorbach 2012]. The privatisation process of the 1980s is often identified as the root cause for such a state of affairs. Through a fairly well-explored movement that gained momentum during the 1980s, the New Public Management school had indeed encouraged the liberalisation, deregulation, and privatisation of public utilities.

In the UK, the energy sector was given pride of place in a venture first introduced by Thatcher and then completed under Major and Blair. Britain stood as a fore-runner by attempting to bring down the existing monopolistic structure of its electricity industry and re-structuring it along competitive lines [Thomas 2004: 3]. The Central Electricity Generating Board was the first to be restructured and divided into three entities; National Power, PowerGen and Nuclear Electric, the transitory company in charge of operating Magnox and AGR nuclear power stations. Privatisation was completed when Nuclear Electric was turned into a fully-fledged private company (British Energy) in 1996. ${ }^{1}$ As Kuzemko highlighted, the weaknesses of the energy transition have their roots in what she calls this 'depoliticisation' process of the 1980s-1990s [2014]. We concur by arguing that limited long-term and sustained state support and involvement substantially hampered the development and growth of its domestic nuclear [Thomas 2004] and wind power [Simmie, Sternberg and Carpenter 2014] technologies and capabilities. The waning presence of the UK state in an industrial sector which had previously been protected by public regulation therefore tallies with Rhodes's theory of the weakening of the State capacity, as it relinquished direct ownership of the most profitable parts of its operating energy structures to private actors.

As Moran underscored, 'liberalisation and privatisation led the way in redefining the boundaries between the public and the private' [2003: 3] and these were embodied in the concept of 'associative governance' [Bell and Hindmoor 2009: 164] through the empowerment of private investors, as technological and commercial electricity resources turned into a bargaining tool between the UK

${ }^{1}$ British Energy was from then on in charge of the AGR power stations, whilst the older Magnox power stations, deemed unattractive for the private sector, remained under public ownership until they were transferred to BNFL in 1998. 
state and specialised private investors and operators. These various actors then came to be increasingly bound within a self-organising network of interdependence which replaced 'the linear model of decision-making based on a one-direction arrow' with 'interactive and multidimensional arrows' [Rhodes 1996: 652].

In the early stages of the political discussion over energy transition in the mid-2000s, the failings in the capabilities of the UK electricity sector claimed central place in a revival of interest among various stakeholders as evidenced through the publication of various public reports. These reports stemmed from a wide array of sources, ranging from public actors, such as the BIS and DTI state departments, to quangos [Sherry et al. 2010] and the House of Lords [2011b], the academic world [Ruffles 2003], and learned societies [The Royal Society 2011], and included the private industrial actors themselves [NIA 2008; Cogent 2009]. All of these reports voiced very similar concerns over the ability of the UK electricity sector to live up to the challenges of the incoming energy transition through a renewable and nuclear renaissance. More specifically, they identified major flaws in the ability of the industries to sustain strong renewable and nuclear research and development (R\&D) and develop a skilled workforce.

\section{Research and development on the wane}

One of the key drivers-or push mechanisms—in the improvement and expansion of low-carbon electricity technologies is in the renewal of knowledge through steady R\&D spending [Tagwitz and Miola 2005]. Yet the New Public Management rationale that prevailed over the need to give more leverage to private stakeholders translated into cuts in scientific state funding, as 'the government believe[d] that innovation is best achieved by industry reacting to market forces without interference' [Edgerton and Hughes 1989: 424]. In other words, industry knew best when it came to choosing which paths to follow in research and development, being in immediate contact with the demands and expectations of the markets. Consequently, the Centre for the Exploitation of Science and Technology was established with both government and industry funding in the late 1980s. Its primary mission was to identify the strategic areas of science that would be 'commercially exploitable' and therefore worth promoting based on performance and competitiveness. This vision was first introduced in the 1988 White Paper, Department for Enterprise [DTI 1988], and then clearly mapped out in the 1993 Realising our Potential: A Strategy for Science, Technology and Engineering [Chancellor of the Duchy of Lancaster 1993]. In these two documents, the term 'enterprise' became a pivotal concept, symbolic of a strong shift in approach: here industries and private companies were pushed to the fore in a more economically-minded R\&D process as 'economic decisions are best taken by those competing in the market place' [ibid.]. However, introducing market-based dynamics didn't simplistically entail private industries maintaining complete control of $R \& D$, as underlined here: 'open markets are not to be confused with unfettered market forces for these 
Figure 1. Gross domestic expenditures on overall UK R\&D

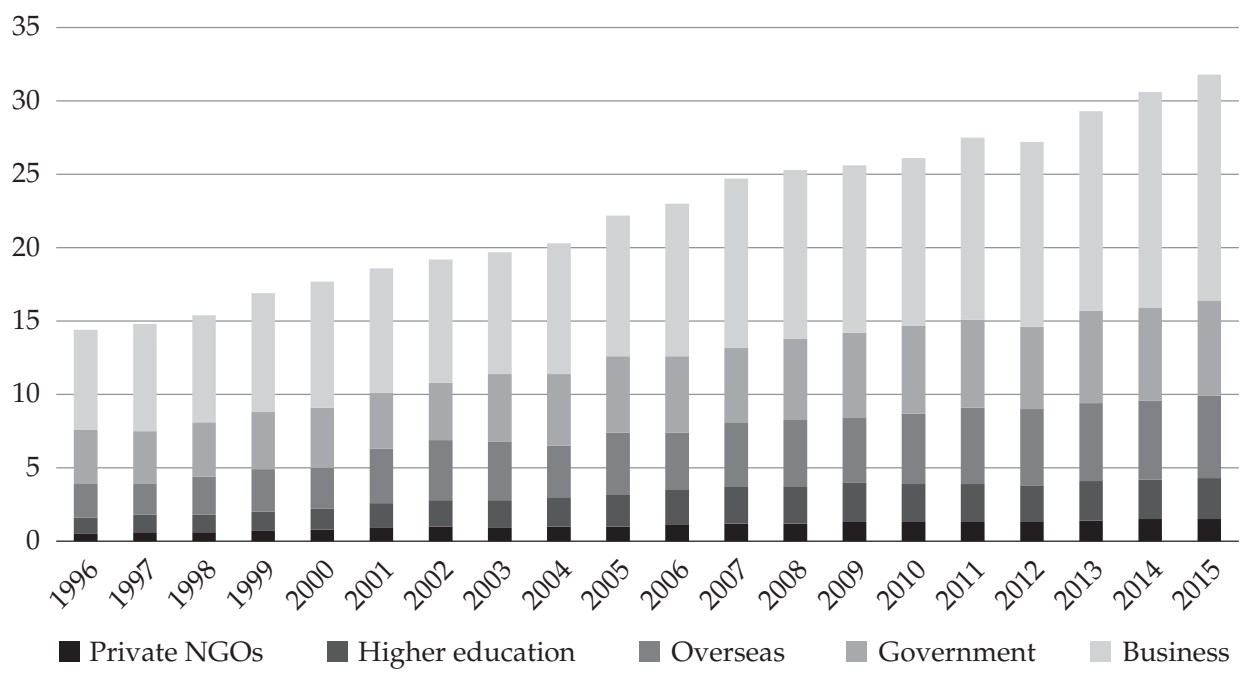

can lead to closed, protected and monopolistic conditions .... Open markets do not mean that governments should rely simply on the operation of market forces or stand by as passive observers of the economy' [House of Commons 1988: 821]. The idea was therefore to foster standard competition policy whilst still leaving windows of interaction open between the market and the relevant public authorities. Nonetheless, a number of public research laboratories on energy production were closed down between the early and the mid-1990s. These political decisions bore three major impacts on the UK energy R\&D capabilities.

Firstly, official figures reveal that a predictable contraction of public funding took place in the early 1990s; the UK's overall gross expenditure on R\&D declined from $1.89 \%$ to $1.64 \%$ of GDP between 1990 and 1997 [ONS 2014: 4]. The trend would somehow be curbed under the first Blair government, although profitability rhetoric and the limited links between government and industries remained unaltered [Lawton-Smith 2006: 91]. Secondly, visible alterations also emerged to the origins of the overall research funding, as illustrated by Figure 1.

This graph shows that, besides a clear contraction in public funding in relative terms, the research budget also experienced a clear shift of its centre of gravity towards other private or exterior actors-be they domestic or foreign businesses, NGOs, or foreign entities such as the EU-who became the primary investors in British energy research projects from 1993 onwards. This dynamic quickened until the advent of the 2008 economic crunch. According to the Office of National Statistics, total British spending in R\&D rose from 20 to 27 billion pounds between 1995 and 2011. Yet adjusted for inflation, this meant that overall 
Figure 2. UK Public R\&D spending recipients for electricity-related projects in millions of Euros between 1974 and 2013

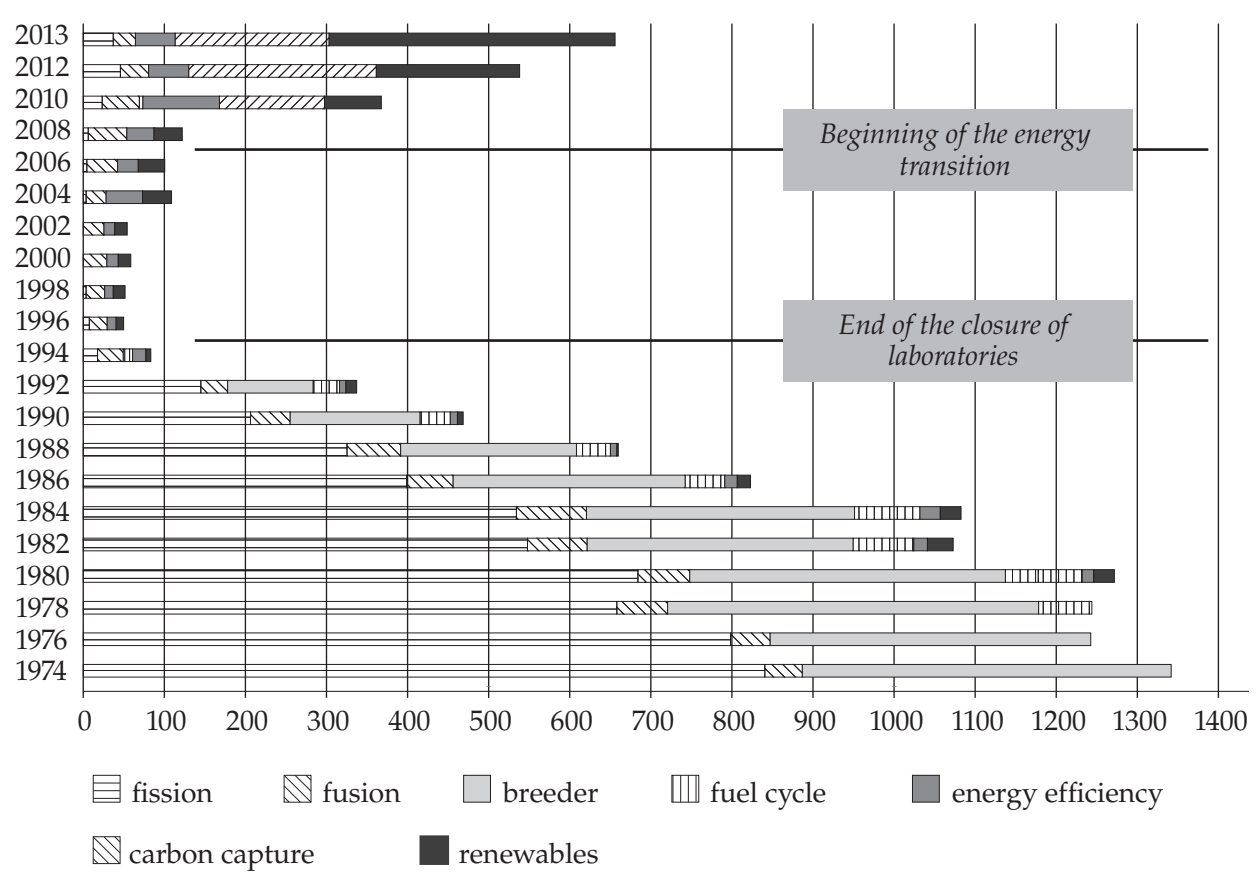

spending did not rise over the same period, thus implying that the decrease in public spending was offset by the rise in private investments that became much more international in scope [Horrocks 2007]. Spending in electricity R\&D followed a similar trend. Thirdly, the House of Lords evidence on the capabilities of nuclear R\&D shed light on the various systemic issues incurred from this partial contraction and privatisation of research funding in the late 1980s/early 1990s [2011a], which had clear consequences on the nature of the research carried out on electricity-generation projects, as illustrated by Figure 2 .

Structurally speaking, private investors tend to provide subsidies to much more targeted and small-scale research projects [Sherry 2010: 44]. As Figure 2 shows, it turned out that a similar trend emerged regarding UK public spending in electricity R\&D in the wake of the privatisation process. Between 1986 and 1996, the share of public R\&D spending on long-term and large-scale projects, nuclear fusion, fast breeders, and fuel cycles was drastically reduced sometimes to nothing. These facets of R\&D attracted very little attention from the private sector as well and therefore lost ground in the UK. Under New Labour, only short-term and medium-term projects such as the increase in renewables and 
energy efficiency secured the very little that remained of state financial support. Renewable R\&D on onshore and offshore wind power, which had started to develop in the mid-1970s, remained fairly limited in scope, being blighted by a very weak collaboration between scientific institutions and industry [Simmie, Sterberg and Carpenter 2014]. Overall, the landscape of private and public energy research funding programmes became uncoordinated, fragmented, fairly short-term in nature and objectives, and increasingly reliant on more immediate technological and political demands. As Nuttall argued, this crumbling of the R\&D capabilities in energy innovation long remained under the public radar due to the implosion and partial privatisation of the sector, which disempowered its actors and prevented any comprehensive and long-term strategy from being formulated [2005: 77].

In other words, liberalising British $R \& D$ gave rise to a much more fragmented research structure, undermined by chronic under-investment. The drop in interest in long-term research projects from both the private and public investors reveals a lack of both state-market coordination and long-term research strategies that strongly hampered energy innovation in the nuclear and renewable sectors. This bleak R\&D outlook partially accounts for a strong shift in the country's energy strategy by $2009 / 2010$. Yet, as these issues and shortcomings started surfacing in the mid-2000s, the UK government set out to introduce several 'decompartmentalising' initiatives, which helped reshape the relationships between public actors and private investors.

\section{New hybrid methods of revamping boundaries between public and private actors}

\section{Restructuring: from quangos to Go-Cos}

From 2005 to 2016, a second phase in the regulation of the British nuclear industry was enacted, as the New Labour governments revealed their own interpretation of Thatcher's agenda of rolling back the limits of state intervention in industrial and energy policies. In addition to introducing market-based measures in energy regulation, several forms of hybrid boundary units were established in this domain, less in the form of private-public partnerships than in quangos and 'government-owned, contractor-operated' (Go-Co) entities. These new units participated in the further erosion and temporary abolition of barriers between private and public actors, between private industrial partners and the energy Department $\left(\mathrm{DECC}^{2}\right)$ in what were deemed mutually-profitable contractive relationships.

${ }^{2}$ Department of Energy and Climate Change (DECC); created in 2008 and dissolved in July 2016. 
In the 2004 Energy Act, for instance, BNFL (British Nuclear Fuels Ltd) was gradually and methodically dismantled and sold to private entities (Toshiba, Energy Solutions, Babcock) between 2005 and 2010 - the year it ultimately disappeared. Yet, two facets of BNFL were left aside and escaped privatisation in 2005 by being morphed into two quangos, or arm's length bodies, sponsored by DECC: The National Nuclear Laboratory (NNL) and the Nuclear Decommissioning Authority (NDA).

The goal of the latter was to deal with the legacy of previous nuclear programmes in a sustainable manner, NDA mostly operated by outsourcing most of its services and commercial responsibilities to private companies. Over $95 \%$ of NDA's annual expenditure was drawn from these outsourcing contracts. According to a bidding contracting process designed to foster competition, these private companies were thus in charge of operating the sites which were to be decommissioned. For example, the tasks of cleaning and decommissioning the Sellafield site were entrusted to a consortium of three private companies, The Nuclear Management Partners in 2008. By the end of their contract in 2015, the dismantling of Sellafield was taken over by another private contractor; Cavendish Fluor Partnership.

At first sight, this practice emerges as a traditional alternative to privatisation and contractualised forms of collaborations between public and private entities known as public-private partnerships (PPPs), which flourished under New Labour. Closer analysis however reveals that the contracts awarded by NDA go beyond the standards of basic PPPs. Nuclear Management Partners Limited and Cavendish Fluor Partnership, for instance, engaged in more than mere outsourcing. Under the terms of the contract, each entity or consortium became a 'parent body organisation', meaning that as such they became the temporary owner providing strategic management of the companies in charge of the dismantling operations, 'the site licence companies' [GB National Audit Office 2012]. Under the terms of the five-year renewable agreement, Sellafield Limited, the public site licence company or onsite service provider, was no longer in direct contact with its government body, NDA.

Overall, these new sub-contracting practices not only added to the complexity of the interface entities, but also entailed a shift from short-term to more long-term structural partnerships, which endowed the 'parent-body organisation' with greater action leverage. In practice, the parent body organisation temporarily became the main stakeholder of, and therefore investor in, the public onsite service provider.

From 2004 onward, this multi-layered structure of NDA revealed the logics of extreme sub-contracting, here going beyond the translation of PPPs into industrial terms [Ilchong and Rothwell 2014], through the emergence of Go-Cos. Such partnerships involving private and foreign stakeholders theoretically help to inject greater expertise into the provider's practices and quicken the pace of a more cost-effective dismantling process. As for NDA, the Go-Co facilities en- 
tailed a financial windfall as one third of its 2015 budget was actually generated from these commercial activities. During the first five years, up to $50 \%$ of NDA's budget came from its Go-Cos.

By resorting to Go-Cos, the state seemingly became a broker of nuclear services, having agreed to give up its political control over the business. ${ }^{3}$ In practice, however, the state has still kept its name on the title deeds. This may seem a paradoxical position, especially given the effective privatisation of the other subsidiaries of BNFL. It thus seems that Go-Cos enabled the government to cement and institutionalise their contractive links with their private partners, whilst still preserving the option to take control back from private actors for strategic purposes. At the same time, Go-Cos allow the private companies involved to gain more temporary leverage in decision-making over their activities. Such a restructuring process was accompanied by a revamped R\&D strategy.

\section{Science's New Deal: the revival of the Triple Helix}

A different organising strategy emerged more clearly in the 2012 action plan entitled Nuclear Industrial Strategy under the authority of both the Department for Business, Innovation and Skills (BIS) and DECC. ${ }^{4}$ This report offered a new roadmap to reactivate and bolster the ties between academia and industry, deemed too fragmented and disconnected both in terms of resources and objectives [DECC 2013: 5]. All of these strategic schemes involving industry, academia, and public authorities were established through the patronage of the UK government.

Firstly, several formal academic-industrial strategic partnerships were forged or strengthened. These involved prominent universities and key sectorial actors from the nuclear or renewables markets, including operators such as EDF Energy or E.On, and constructors/supply chain leaders, like AMEC or Rolls Royce, as illustrated in Table 1.

Secondly, the state's industrial strategy to prepare for energy transition went further than these formal attempts at catalysing interactions amongst the three hubs for research purposes. If the universities' objectives were turning industrial, a similar hybridisation trend seemed to be under way within the industry, where targeted training has been offered to meet the country's future needs in terms of skilled renewable and nuclear workforces. For instance, the nucleargraduates programme launched by NDA in 2008 has been funded and managed by sev-

\footnotetext{
${ }^{3}$ By 2008 most of the remaining nuclear research entities (Windscale, Preston, Workington, Harwell, Stonehouse and Risley) had merged to form the National Nuclear Laboratory (NNL). The NNL remained under public ownership (DECC), yet its management was sub-contracted to managing contractors, under a structure similar to that of the NDA a Go-Co.

${ }^{4}$ Presented at the YGN one-day industrial conference at Westminster on 25 April 2012.
} 
Table 1. Examples of academia-industry research partnerships in energy transition

\begin{tabular}{|c|c|c|}
\hline PARTNERSHIPS & ACADEMIA & INDUSTRY \\
\hline $\begin{array}{l}2001 \\
\text { The Immobilisation Science } \\
\text { Laboratory (ISL) }\end{array}$ & Sheffield University & $\begin{array}{l}\text { BNFL Research and } \\
\text { Technology Dvisions, } \\
\text { NIREX, AWE. }\end{array}$ \\
\hline $\begin{array}{l}2006 \\
\text { The Energy Research } \\
\text { Partnership (EPR) }\end{array}$ & $\begin{array}{l}\text { University of Cambridge } \\
\text { Royal Academy of } \\
\text { Engineering }\end{array}$ & $\begin{array}{l}\text { Bosch Thermotechnology } \\
\text { Ltd, Hitachi Europe Ltd, } \\
\text { Drax Power Ltd, EDF } \\
\text { Energy, Atkins, E.On }\end{array}$ \\
\hline $\begin{array}{l}2006 \\
\text { Centre for Nuclear } \\
\text { Engineering (CNE) }\end{array}$ & $\begin{array}{l}\text { Manchester, Strathclyde, } \\
\text { Surrey, Lancaster, Leeds, } \\
\text { Cambridge Universities, } \\
\text { Imperial College, Open } \\
\text { University }\end{array}$ & $\begin{array}{l}\text { Rolls Royce, EDF Energy, } \\
\text { Sellafield Ltd, NNL }\end{array}$ \\
\hline $\begin{array}{l}2007 \\
\text { The Systems Performance } \\
\text { Centre }\end{array}$ & Bristol University & British Energy \\
\hline $\begin{array}{l}2009 \\
\text { Centre for Doctoral } \\
\text { Training (CDT) }\end{array}$ & $\begin{array}{l}\text { Manchester and Sheffield } \\
\text { Universities }\end{array}$ & AMEC and the NDA \\
\hline $\begin{array}{l}2011 \\
\text { PhD Research } \\
\text { collaborations on } \\
\text { Renewable Energy }\end{array}$ & Durham University & DONG Energy \\
\hline $\begin{array}{l}2013 \\
\text { The Offshore Energy } \\
\text { and Coastal Engineering } \\
\text { Research Programme }\end{array}$ & $\begin{array}{l}\text { Manchester University } \\
\text { University of Edinburgh, } \\
\text { Oxford and Queens in } \\
\text { Belfast. }\end{array}$ & $\begin{array}{l}\text { EDF Energy, E.On, Alstom } \\
\text { Company GL Garrad } \\
\text { Hassan }\end{array}$ \\
\hline
\end{tabular}

eral companies from the nuclear industry. The purpose of this undergraduate programme was to train future nuclear professionals through specialised onsite internships. ${ }^{5}$ The turn of the 2010s therefore saw the establishment of several new entities aimed at bolstering strategic coordination between government, academ$\mathrm{ia}$, and industry to lay the foundations for more converging sets of interests and improving not only R\&D but also capacity building (Table 2 ).

${ }^{5}$ Online resource: https://targetjobs.co.uk/employer-hubs/nucleargraduates (retrieved 17 July 2015). According to a Guardian survey, nucleargraduates ranked 130 on the list of most popular employers amongst young graduates. 
Table 2. Examples of new hybrid strategic and coordinating consortia established between 2008 and 2017

GOVERNMENT/INDUSTRY

Nuclear Industry Council Collaborative forum created in 2013.

(NIC)

Includes most of the major private actors (AMEC,

Areva, Babcock, Westinghouse, Hitachi, Rolls Royce, the NIA).

GOVERNMENT/ACADEMIA

Nuclear Innovation and

Set up in 2014.

Research Advisory Board

(NIRAB)

Mostly aiming at informing and advising the government and funding entities on research priorities.

Helps coordinate research programmes.

\section{INDUSTRY / ACADEMIA}

The National Skills

Academy for Nuclear

(NSAN)
Set up in 2008 under the industry initiative (AMEC,

Sellafield Ltd, EDF, Areva UK Rolls Royce)

Coordinating theoretical and practical training in collaboration with the NNL, Prospect (Trade Union) and COGENT.

\section{GOVERNMENT/ INDUSTRY / ACADEMIA}

The Nuclear Advanced Manufacturing Research Centre (NAMRC)

Energy Technology Partnership (ETP)

National Nuclear User Facility (NNUF)

National Skills Academy for Power

Offshore Renewable Innovation Hub
Set up in 2009 as a supporting structure to the nuclear industry.

Main actors: Sheffield and Manchester Universities, and Rolls Royce and EDF UK.

Participated in selecting future supply chain.

Set up in 2012.

Funded by the Scottish government.

Aimed at catalysing the Knowledge Exchange

Network including academia and energy companies to usher in the low-carbon transition in Scotland.

Set up in 2013.

Puts nuclear experimentation material at the disposal of both academia and industry.

Set up in 2010.

Aims at meeting the demands of nuclear and renewable operators in skilled labour supply.

Set up in 2017.

Aims at bringing most stake-holders together to foster innovation and cost-reduction 
In 2012 the then DECC Minister of State underlined that the UK government was the prime engine driving most of these ventures by 'pushing for UK firms to get involved in this joint initiative between university of Sheffield, Manchester and industrial partners from across the manufacturing sector' [Hendry 2012]. ${ }^{6}$ Similarly, a NAMRC representative stressed the urgent need 'to align UK companies in a timely manner to be ready to address nuclear manufacturing requirements [and] to close the capability gap'. ${ }^{7}$

Thirdly, by the turn of 2010, the UK departments involved in energy also engaged in a complex communication campaign by organising and participating in a large number of state-industry conferences. These various initiatives were aimed at fulfilling a clearly strategic aim, but not at meeting democratic and communication demands regarding the decision-making process. They therefore purposefully excluded civil society. At the 'Nuclear Investors Conference' organised by the Department for Business Enterprise and Regulatory Reform (BERR) in 2012, the purpose was to bring together 'financial institutions, consultancies, insurance underwriters, construction companies, decommissioning agencies, regulatory authorities, trade unions, business representatives, specialist suppliers, academics from leading universities'. However, the Non-Governmental Organizations (NGOs) of the environmental movement did not attend the conference. This was because the stated purpose of the NIC was to discuss investment and the development of the industry and as such the input of the NGOs was not considered essential to the discussion' [Baker, Simpson and Stoker 2012: 2].

All in all, these new state-organised forums of interaction and exchange between government, academia, and industry also revealed an attempt to strengthen private investors' confidence in the government's commitment to pave the way for the energy shift. At another industrial conference on the nuclear future held at Westminster in 2012, Jenkin of Roding admitted that 'the government acknowledged their responsibility in R\&D and the need to adopt a more coherent strategy'. ${ }^{8}$ Similarly, the Treasury report on nuclear R\&D strategy released in 2013 insisted on the absolute need for state-industry collaboration to address policy needs as 'government and industry [would] also set out their shared vision to realise the potential for growth and jobs in the private sector, building on UK strengths and experience' [HM Government 2013: 10].

These three platforms revealed another key rationale as the idea here was not only to facilitate such a transition by strengthening the UK labour force, supply chain, and manufacturing technologies, but also to coordinate structures and

\footnotetext{
${ }^{6}$ From a presentation attended by the author and delivered by Charles Hendry at the private Industrial Conference, 'A Balanced Future', organised by the N.O.E in Manchester on 7 March 2012.

${ }^{7}$ Quote from a presentation given by Martin Ride, a NAMRC representative, at the N.O.E. conference; see footnote 6 .

${ }^{8}$ From a presentation attended by the author and organised by the Nuclear Institute Young Generation Network at Westminster on 25 April 2012.
} 
commercial practices to standardise and possibly internationalise the domestic electricity industry, as argued by John Hutton, a government representative at the 2012 Nuclear Investors Conference [Baker, Simpson and Stoker 2012: 3]. Participating in such joint ventures allowed industry actors to achieve similar aims but also to greenwash their practices as in recent years business increasingly has been viewed as a major cause of social, environmental, and economic problems. Companies are widely perceived to be prospering at the expense of the broader community' [Porter and Kramer 2011: 64]. In other words, these three recent programmes somehow morphed centres of academic expertise into 'innovative enterprises', and industrial partners into active agents in the ethical and socially-acceptable task of answering policy needs and bridging the human and technological gap on the path to low-carbon energy production.

This R\&D strategy also led to developing innovative practices to tighten the links between industry and academia. The second component of the sustainable industrial strategy (industry-academia consortia) was based on formalised partnerships inspired by traditional University-Industry Collaboration (UICs). UICs are commonly characterised by research support, cooperative research, knowledge transfer/creation and technological exchanges [Santoro and Gopalakrishnan 2000]. Yet, besides these traditional aspects, these consortia also boasted innovative features including industrially-sponsored $R \& D$ in university departments, students' involvement in industrial projects, the hiring of graduate students or joint research programmes. According to Ankrah and Al-Tabbaa, these are advanced and original organisational forms for UICs [2016: 391]. That these various forms of industry-university collaboration ventures were defined by government and originated in semi-public or state entities also adds to their innovative nature.

All in all, these forms of strategic interdependence were institutionalised in an enduring market-based economic context. This tripolar collaborative structure thus reactivated the Triple Helix model, putting an end to the traditional theoretical divergence between the Humboldtian education model, the practical short-term and profit-driven objectives of the industry, and the traditional view depicting universities in their ivory towers pursuing 'blue-sky' research. In other words, the energy transition also helped entrench the interactions between private actors and the academic sphere in what could be approached as a third academic revolution [Etzkowitz 2003]. State oversight and steering, along with industry compliance and involvement undoubtedly acted as critical driving and organisational forces in innovation policy [Perkmann, Neely and Walsh 2011; Ranga and Etzkowitz 2013].

\section{Rejuvenated funding schemes}

Mostly set up under the Blair, Brown and coalition governments, the previously mentioned industry-academia partnerships and consortia benefitted from funding allocated through the Engineering and Physical Research Council (EPSRC), 
along with DECC and NDA. These entities released substantial funds to support the initiatives sponsored by the innovative coordination consortia. In 2009 the Labour Government thus injected GBP 15 million into the NAMRC project for instance [World Nuclear News 2009]. In July 2017, the EPSRC awarded the universities of Durham, Hull and Sheffield, along with industry partners (Siemens, Gamesa Renewable Energy and DONG Energy) GBP 7.6 million in funding to conduct research in offshore wind power technologies. Funding opportunities through EPSRC therefore allowed the government to identify strategic priorities and encourage private actors and academia to partake in a politically-determined but more comprehensive approach to electricity production.

The green agenda coupled with the 2008 economic downturn allowed DECC to invest millions of pounds in wind and nuclear R\&D thanks to their low-carbon credentials through various economic development programmes, included in the policy paper Building Britain's Future released in 2009. The Regional Growth Fund (2011-2015) was also established by the Treasury to support projects that could stimulate economic growth and job creation in earmarked regions. Sheffield University was thus granted GBP 37 million to further collaborate with NARMC $^{9}$ as part of this GBP 2.4-billion programme. Similarly, Innovate UK, the state agency providing innovation support based on calls for tender, combined with DECC and NDA to co-fund several large and medium scale programmes in nuclear R\&D carried out by industry (EDF, Sheffield Forgemasters, and several SMEs) and universities, two of which were launched in March 2013 (GBP 31 million) and October 2014 (GBP 13 million) [Gov.UK 2013]. ${ }^{10}$ Finally, Theresa May's Government carried on down that road by awarding substantial funding of up to GBP 177 million to renewable wind energy and bioenergy through BEIS, ${ }^{11}$ Innovate UK, and Research Councils.

It is therefore either through the Engineering and Physical Research Council, or through indirect/direct support schemes to innovation and economic development that the UK governments have managed to subsidise actors from the nuclear and renewable industry from 2009 to the present. As noted by Ćetković and Buzogány, wind energy was rather slow to develop during the 1990s, but started to pick up between 2010 and 2015 thanks to this more supportive state investment policy, which was further bolstered by the 2009 EU Renewables Directives [2016: 7].

However, these funding priorities provoked sharp criticism, being interpreted as evidence of a final nail being driven into the coffin of the Haldane principle and revealing that academia was being harnessed to serve and accommodate po-

\footnotetext{
9 See Table 2.

${ }^{10}$ Gov.uk. 26/03/2013. ' $£ 31$ Million injected for New Nuclear Technologies.' Press release, https://www.gov.uk/government/news/31-million-injection-for-new-nuclear-technology-in-the-uk (retrieved 4 September 2017).

11 BEIS is the Departement for Business, Energy and Industrial Strategy, following the merger of DECC and BIS in 2016.
} 
litical and private design [Chitty 2011] —namely in the promotion of nuclear and offshore wind power. Through these investment schemes the state indeed steered private investors towards favoured manufacturing capacities for specific technologies, namely nuclear and offshore wind power [Ćetković and Buzogány 2016]. Offshore wind and nuclear power therefore expanded at the expense of onshore power, which has remained modest and has not been successfully developed by mainly foreign investors [IRENA 2012: 130; Simmie, Sternberg and Carpenter 2014], except in Scotland where devolution has helped local governments to be more supportive of onshore wind power [BEIS 2017: 173]. Political choices thus impacted the technological paths taken by private investors by constraining domestic wind capacities [Wieczorek 2013]. According to European Commission figures, the largest share of R\&D spending on wind energy came from the state rather than industrial actors [European Commission 2013: 38-39]. As a result, the UK had an installed capacity of 5,098 MW from operational offshore wind power, which accounted for $45.9 \%$ of the entire EU market in 2015 [BEIS 2017: 156]. As many commentators have suggested, the relative success of the offshore wind sector derives from its certain compatibility with existing national political and economic imperatives [Ćetković, Buzogány and Schreurs 2017: 114]. Both nuclear power and offshore technologies fall in line with conventional energy projects in terms of planning and implementation, being thus familiar to both government and private investors. Such a centralised structure therefore enables private actors to directly interact and co-ordinate their strategic investments with the government [Kern et al. 2014] ${ }^{12}$.

\section{The return of neo-corporatism}

All in all, the previously outlined new coordinating schemes between industry, academia, and the state tend to suggest that the neo-corporatist structure that had flourished before liberalisation has been rejuvenated and reactivated in the UK electricity sector. It indeed seems that the exceptional demands of energy transition tipped the balance towards greater long-term collaboration instead of competition.

Restructuring policies revealed how PPPs or contractive partnerships introduced in the UK nuclear sector drifted towards one client/one service provider bound to long-term structural partnerships (Go-Cos). These partnerships emerged from consortia and allowed actors to perform actions in a monopolistic fashion [Biau and Weil 2006]. In terms of R\&D and technological capabilities, the private sector's interests aligned with public choices, as conveyed through

\footnotetext{
${ }_{12}$ Nonetheless, this political choice has so far proven more successful in Scotland than in England, where the lack of early long-term state support hampered the quick rise of a large-scale domestic offshore wind programme.
} 
funding schemes. The revived Triple Helix helped foster stability, long-term cooperation, and strategic coordination among most private and corporate actors, thus boasting many features of typical tripartite neo-corporatism [Lembruch 1984; Siaroff 1999: 195-196]. The nuclear and renewable industrial strategy introduced in the late 2000s was not only institutionalised as a policy pattern, but also attempted to articulate cooperation among the various interest organisations through an 'authoritative allocation of values' and funding [Lehmbruch 1979: 150]. Drawing on Schmitter's seminal definition, the spectre of neo-corporatism emerged as these strategies tried to foster 'a system of interest representation in which the constituent units are organised into a limited number of singular, compulsory, non-competitive, hierarchically ordered and functionally differentiated categories, recognised or licenced (if not created) by the state and granted a deliberate representational monopoly within their respective categories in exchange for observing ... and articulation of demand and supports' [1979: 13].

Besides coordinating innovation and development trajectories, the industrial approach thus at work in the UK electricity sector has also fulfilled other functions, including visibility, networking, and the pooling of resources, expertise, and funding. Mostly spurred by energy transition demands, this approach can only be successful provided that cooperation is secured from industrial partners that are traditionally in competition with each other. It therefore follows that this new hybrid industrial strategy resulted from negotiations between industry and government-as was the case during the 2013 reform of electricity regulation [de Carvalho 2017]. As Edgerton and Hughes suggested, 'government intervention is necessary for stable growth, to ensure that the economy achieves the right level and direction of innovative activity, especially in the transition from one paradigm to another' [1989: 421]; and one may also add here the collaboration of private actors.

Overall, this overview of the recent industrial strategies implemented in the UK to trigger a long-term low-carbon transition has revealed that private actors are no longer confined to implementing or funding technology choices. Through their involvement in R\&D and training consortia and policy design, 'private interests' have participated in moulding the shape of Britain's energy mix. Consequently, labelling discourses to describe these actors tended to shift from 'private interests' or 'private investors' to active 'industrial partners'.

\section{Government and private actors as joint architects in Britain's energy policy}

Falling in line with existing literature on the opposition between public and private sectors, this analysis shows how neo-liberal practices and the substantial number of joint ventures did not result in redefining the boundary between the two sectors in a more visible way-quite the opposite. The exceptional demands of energy transition ushered in new borderline dynamics which transformed the 
boundary into a continuum of interactions. These new arrangements sharply redefined the very notions of 'vested interests' and 'public choice'. The present study in particular has identified a strengthened model of interaction between private and public bodies based on a revived Triple Helix boasting several neocorporatist features. This model aims to replace neo-liberal competition with organic cooperation through an actor-based network. As things now stand, this model has produced encouraging results regarding the expansion of offshore wind power, as Britain has gone from 'laggard' to 'leader' in the area over the past seven years [Kern et al. 2014]. As for the nuclear renaissance, results have been more lukewarm, as only one nuclear power station is presently under construction and as private actors have been slow to join the venture-yet the tide is turning [Vaughan 2017]. Despite the results in terms of low-carbon capabilities, which should be interpreted with care, this model of interaction is symptomatic of underlying shifts in the role and values allotted to the private sector in this eminently strategic decision-making process.

The present case of a systemic shift in electricity policy has revealed deeprooted changes in the roles and objectives not only of the state, but also of private actors as strategic drivers of political and sectoral innovation and transformation. The present study suggests that industry and sectorial actors have been engaging more actively in elaborating the medium-term industrial strategy of the country, particularly on the supply and R\&D sides, since the end of the 2000s. Such a move has been strongly encouraged by the UK state through financial and organisational incentives. Harnessing the support and involvement of private partners has emerged as a crucial parameter to usher in confidence and stability in the transition to low-carbon electricity production, as a result of increasing demands for more formal state guarantees from private actors. In other words, private partners have taken on the roles not only of active drivers of innovation, but also of agents of stability, founding their authority and legitimacy on expertise and capabilities. In so doing, the industry has exercised a stronger influence in the strategic shaping of political decisions, slowly morphing into something akin to agenda-setters.

The state's various attempts at involving the industry in strategic knowledge-transfer and identification of technological possibilities have deactivated the dichotomy between private and public through the alignment of political and economic interests. In that sense, 'markets are a powerful means of enhancing the public interests', as 'entrepreneurs, corporations, and other private sector actors could be manipulated and harnessed for the general public good' [Lee 2011: 47]. Unlike PPPs, which mostly aim to have private actors bear the brunt of funding and handle the delivery of public services, private actors have participated in outlining the shape of the future energy mix of the country by collaborating with academia and government alike. In that sense, 'businesses can assume both a private and a public role" and "in laying claim to the aura of a state actor, they can escape having to compete with other suppliers in doing so' [Stark 2010: 199]. 
Commercial interests have morphed into national interests, and their defence is jointly assumed by both government and industry in a more long-term strategy. The nexus between private and public bodies here has permeated not only role definitions and objectives, but also means of action. This alignment between private and public roles, interests, and activities has therefore entailed the rise of a new continuum of interactions in the hybrid zone between the two sectors.

\section{Conclusion}

This analysis has revealed how pressures on the UK's industrial and innovation capabilities have played a crucial role in policy-making and in redefining the interactions between the various actors involved in electricity policies. Determining what is properly private and what is properly public is proving increasingly challenging. Since the late 2000s, the energy transition has prompted both government and industry to engage in a more collaborative and anticipatory R\&D and supply strategy. It turns out that private actors no longer merely deliver services or invest in new innovative ventures, but also facilitate, promote and feed the transition towards a decarbonised electricity system. Through the hybrid Go-Cos, and industry-academia-government consortia and strategic partnerships funded by both private and public money, the two sectors increasingly overlap and interlock. De facto, this government-industrial partners continuum henceforth bears the hallmarks of both economic and environmental sustainability, thus legitimising the involvement of the private sector in energy policy as part of their 'corporate social responsibility' [Riess 2012].

However, as visible results have been slow to appear, such a revival of the private-public continuum based on interdependence remains a pragmatic political reaction. Roles and interactions are not set in stone, but liable to constant change and redefinition, just as actors are not 'passive rule-followers' but 'active rule users and makers' [Geels and Schot 2007: 403], and in that sense, may be strongly motivated by contingent factors. The immediate demands of the exceptional context of the energy paradigm shift highlight the potential role of the energy transition as a key structural incentive. We therefore assume that this alignment of public and private interests remains a transient dynamic, reflecting the intrinsically transitional nature of policy-makers and private actors' roles and interactions [Wittmayer et al. 2017]. As Ahlborg argued, each party's power and involvement remain fundamentally 'relational, contingent and situated' [2017: 1]. To put it differently, the increasingly synergetic interactions between industry and government analysed here may only be temporary, as sustainability has turned into a temporary matter of national interest. Just like the energy transition has spurred a renewal in terms of instruments and approaches in the design of the national energy mix, the author of this paper therefore encourages further empirical research on the re-definition of actors' participation in public affairs in terms of resources, instruments, roles and values. 
LUCIE DE CARVALHO is a senior lecturer in British history and politics at the University of Lille (France). Her research focuses on nuclear power policies in the UK since the 1970s. She is interested in the roles assumed by the UK state in energy decision-making. She is currently preparing a book entitled Nuclear Power Policies in the UK: the Quandaries of Neoliberalism.

\section{References}

Ahlborg, H. 2017. 'Towards a Conceptualisation of Power in Energy Transition.' Environmental Innovation and Societal Transitions 25: 122-141, https://doi.org/10.1016/j.eist.2017.01.004.

Ankrah, S. and O. Al-Tabbaa. 2015. 'Universities-Industry Collaboration.' Scandinavian Journal of Management 31: 387-408, https://doi.org/10.1016/j.scaman.2015.02.003.

Baker, K., J. Simpson and G. Stoker. 2012. "'The Nuclear Investors Conference.' A SPRing Working Report. Southampton: University of Southampton.

BEIS. 2017. Digest of UK Energy Statistics. London: TSO.

Bell, S. and A. Hindmoor. 2009. Rethinking Governance: The Centrality of the State in Modern Society. Cambridge: Cambridge University Press, https://doi.org/10.1017/СВO9780511814617.

Biau, V. and S. Weil. 2006. 'Comprendre les Pratiques Européennes: Evolution de la Politique PFI Concernant les Bâtiments Publics en Grande-Bretagne.' Rapport d'Enquête. Paris : Centre d'Expertise Français pour l'Observation des Partenariats Publics-Privés (CEF-O-PPP).

Ćetković, S. and A. Buzogány. 2016. 'Varieties of Capitalism and Clean Energy Transitions in the European Union: When Renewable Energy Hits Different Economic Logics.' Climate Policy 16 (5): 642-657, https:// doi.org/10.1080/14693062.2015.1135778.

Ćetković, S., A. Buzogány and M. Schreurs. 2017. 'Varieties of Clean Energy Transitions in Europe: Political-Economic Foundations of Onshore and Offshore Wind Development.' Pp. 642-657 in The Political Economy of Clean Energy Transition, edited by D. Arent, C. Ardnt, M. Miller, F. Tarp and O. Zinaman. Oxford: Oxford University Press.

Chancellor of the Duchy of Lancaster. 1993. Realising our Potential: A Strategy for Science, Technology and Engineering. London: HMSO.

Chitty, A. 2011. 'Burying the Haldane Principle.' Storm Breaking upon the University. Retrieved 20 November 2018 (http://stormbreaking.blogspot.com/2011/04/burying-haldane-principle.html).

Cogent. 2009. Power People: The Civil Nuclear Workforce, 2009-2025. Renaissance Nuclear Skills Series 1. Warrington, DC: Cogent.

Cooper, T. 1985. 'The Public-Private Continuum: Interdependence in a Democratic Society.' Public Budgeting and Finance 5 (3): 99-115, https://doi.org/10.1111/1540-5850.00693.

de Carvalho, L. 2017. 'Austerity Policies, the UK State and the Energy Utilities: A Changing Paradigm or Business as Usual?' The Political Quarterly 8 (3): 425-433, https://doi.org/10.1111/1467-923X.12377.

DECC. 2013. Nuclear Energy Research and Development Roadmap: Future Pathways. London: TSO.

DTI. 1988. The Department for Enterprise. London: HMSO. 
DTI. 2007. Meeting the Energy Challenge: A White Paper on Energy. London: HMSO.

Edgerton, D. and K. Hughes. 1989. 'The Poverty of Science: Critical Analysis of Scientific and Industrial Policy under Mrs Thatcher.' Public Administration 67 (4): 419-433, https://doi.org/10.1111/j.1467-9299.1989.tb00739.x.

Etzkowitz, H. 2003. 'Innovation in Innovation: The Triple Helix of University-IndustryGovernment Relations.' Social Science Information 42 (3): 293-338, https://doi.org/10.1177/05390184030423002.

Farla, J., J. Markard, R. Raven and L. Coenen. 2012. 'Sustainability Transitions in the Making: A Closer Look at Actors, Strategies and Resources.' Technological Forecasting and Social Change 79 (6): 991-998, https://doi.org/10.1016/j.techfore.2012.02.001.

Favarel-Garrigues, G., T. Godefroy and P. Lascoumes. 2007. 'Sentinels in the Banking Industry: Private Actors and the Fight against Money Laundering.' Sociologie $d u$ Travail 49 (1): 10-27, https:// doi.org/10.1016/j.soctra.2006.12.005.

Fischer, L.-B. and J. Newig. 2016. 'Importance of Actors and Agency in Sustainability Transitions: A Systematic Exploration of the Literature.' Sustainability 8: 476-497, https://doi.org/10.3390/su8050476.

Geels, F. 2004. 'From Sectoral Systems of Innovation to Socio-Technical Systems: Insights about Dynamics and Change from Sociology and Institutional Theory.' Research Policy 33 (6-7): 897-920, https://doi.org/10.1016/j.respol.2004.01.015.

Geels, F. and J. Schot. 2007. 'Typology of Sociotechnical Transition Pathways.' Research Policy 36 (3): 399-417, https:/ / doi.org/10.1016/j.respol.2007.01.003.

Geels, F. 2010. 'Ontologies, Socio-Technical Transitions (to Sustainability), and the MultiLevel Perspective.' Research Policy 39: 495-510, https://doi.org/10.1016/j.respol.2010.01.022.

Grin, J., J. Rotmans, J. Schot, D. Loorbach and F. Geels (eds). 2010. Transitions to Sustainable Development; New Directions in the Study of Long-Term Transformative Change. New York: Routledge, https://doi.org/10.4324/9780203856598.

Habermas, J. (1962 translated 1989). The Structural Transformation of the Public Sphere. Cambridge: Polity.

Hannesson, R. 2009. 'Energy and GDP Growth.' International Journal of Energy Sector Management 3 (2): 157-170, https://doi.org/10.1108/17506220910970560.

Hedberg, D., S. Kullander and H. Frank. 2010. ‘The World Needs a New Energy Paradigm.' Ambio 39 (1): 1-10, https:// doi.org/10.1007/s13280-010-0057-9.

Helm, D. 2005. 'The Assessment: The New Energy Paradigm.' Oxford Review for Economic Policy 21 (1): 1-18, https://doi.org/10.1093/oxrep/gri001.

Helm, D. 2007. The New Energy Paradigm. Oxford: Oxford University Press.

HM Government. 2013. A Review of the Civil Nuclear RED Landscape in the UK. London: HMSO.

Horrocks, S. 2007. 'The Internationalisation of Science in a Commercial Context: Research and Development by Overseas Multinationals in Britain before the Mid-1970s.' British Society for the History of Science, 40 (2): 227-250, https://doi.org/10.1017/S0007087407009491.

House of Commons. 1988. 'DTI-The Department for Enterprise.' Hansard 19 February, 493 (871).

House of Lords Science and Technology Committee. 2011a. Call for Evidence: Nuclear Research and Development Capabilities. London: The Stationery Office.

House of Lords Science and Technology Committee. 2011b. Nuclear Research and Development Capabilities. Third Report. London: The Stationery Office.

Ilchong, N. and G. Rothwell (eds). 2014. New Nuclear Power Industry Procurement Markets: International Experiences. Seoul: Korea Development Institute.

Kern, F., A. Smith, C. Shaw, R. Raven and B. Verhees. 2014. 'From Laggard to Leader: 
Explaining Offshore Wind Developments in the UK.' Energy Policy 69 (6): 635-646, https://doi.org/10.1016/j.enpol.2014.02.031.

Kuzemko, C. 2014. 'Depoliticisation, Institutions and Political Capacity: Explaining Sedate Energy Transition in the UK.' IGov EPG Working Paper 1405. Exeter: University of Exeter Press.

Lawton-Smith, H. 2006. Universities, Innovation and the Economy. Abingdon: Routledge, https://doi.org/10.4324/9780203358054.

Lee, S. 2011. 'Gordon Brown and the British Way of Risk-based Modernisation.' L'Observatoire de la Société Britannique 10: 45-58, https://doi.org/10.4000/osb.1115.

Lehmbruch, G. 1979. 'Liberal Corporatism and Party Government.' Pp. 91-126 in Trends Towards Corporatism Intermediation, edited by P. Schmitter and G. Lehmbruch. London: Sage.

Lehmbruch, G. 1984. 'Concertation and the Structure of Corporatist Networks.' Pp. 60-80 in Order and Conflict in Contemporary Capitalism, edited by J. Goldthorpe. Oxford: Clarendon Press.

Lockwood, M., C. Kuzemko, C. Mitchell and R. Hoggett. 2013. 'Theorising Governance and Innovation in Sustainable Energy Transitions.' IGov Working Paper 1304. Exeter: Exeter University Press.

Markard, J., R. Roven and B. Truffer. 2012. 'Sustainability Transitions: An Emerging Field of Research and Its Prospects.' Research Policy 41: 955-967, https://doi.org/10.1016/j.respol.2012.02.013.

Moran, M. 2003. The British Regulatory State: High Modernism and Hyper-Innovation. Oxford: Oxford University Press, https://doi.org/10.1093/0199247579.001.0001.

Mosley, L. 2009. 'Private Governance for the Public Good? Exploring Private Sector Participation in Global Financial Regulation.' Pp. 126-146 in Power, Interdependence, and Nonstate Actors in World Politics, edited by A. Moravcsik and H. Milner. Princeton, NJ: Princeton University Press, https://doi.org/10.1515/9781400830787.126.

National Audit Office. 2012. Managing Risk Reduction at Sellafield. London: The Stationery Office.

NIA. 2008. The UK Capability to Deliver a New Nuclear Build Programme 2008 Update. Nuclear Industry Association Report.

Nuttall, William. 2005. Nuclear Renaissance: Technologies and Policies for the Future of Nuclear Power. Oxon: Taylor \& Francis Group.

ONS. 2014. UK Gross Domestic Expenditure on Research and Development. Statistical Bulletin. London: TSO.

Perkmann, M., A. Neely and K. Walsh. 2011. ‘How Should Firms Evaluate Success in University-Industry Alliances? A Performance Measurement System.' RED Management 41: 202-216, https://doi.org/10.1111/j.1467-9310.2011.00637.x.

Perry, J. and H. Rainey. 1988. 'The Public-Private Distinction in Organization Theory: A Critique and Research Strategy.' Academy of Management Review 13 (2): 182-201, https://doi.org/10.5465/amr.1988.4306858.

Pollitt, C. 2003. 'Joined-Up Government: A Survey.' Political Studies Review 1 (1): 34-49, https://doi.org/10.1111/1478-9299.00004.

Ragwitz, M. and A. Miola. 2005. 'Evidence from R\&D Spending for Renewable Energy Sources in the EU.' Renewable Energy 30 (11): 1635-1647, https://doi.org/10.1016/j.renene.2004.12.001.

Ranga, M. and H. Etzkowitz. 2013. 'Triple Helix Systems: An Analytical Framework for Innovation Policy and Practice in the Knowledge Society.' Industry and Higher Education 27: 237-262, https://doi.org/10.5367/ihe.2013.0165.

Rhodes, R. A. W. 1996. 'The New Governance: Governing without Government.' Political Studies 44 (4): 652-667, https://doi.org/10.1111/j.1467-9248.1996.tb01747.x. 
Richmond, A. and R. Kaufmann. 2006. 'Is There a Turning Point in the Relationship between Income and Energy Use and/or Carbon Emissions?' Ecological Economics 56 (2): 176-189, https:/ / doi.org/10.1016/j.ecolecon.2005.01.011.

Riess, B. 2012. Government as Partner? CSR Policy in Europe. Gütersloh: Bertelsmann Stiftung.

Rip, A. and R. Kemp. 1998. “Technological Change." Pp. 327-399 in Human Choice and Climate Change, vol. 2, edited by S. Rayner, S. and E. Malone. Columbus, OH: Battelle Press.

Rotmans, J., R. Kemp and M. Van Asselt. 2001. 'More Evolution than Revolution: Transition Management in Public Policy.' Foresight 3 (1): 15-31, https://doi.org/10.1108/14636680110803003.

Royal Society. 2011. Fuel Cycle Stewardship in a Nuclear Renaissance. London: The Royal Society.

Ruffles, P. 2003. An Essential Programme to Underpin Government Policy on Nuclear Power. Nuclear Task Force. Retrieved 20 November 2018 (http://130.88.20.21/uknuclear/pdfs/Nuclear_Task_Force_July_2003.pdf).

Rutledge, I. and P. Wright (eds). 2010. UK Energy Policy and the End of Market Fundamentalism. Oxford: Oxford University Press.

Santoro, M. and S. Gopalakrishnan. 2000. 'The Institutionalization of Knowledge Transfer Activities within Industry-University Collaborative Ventures.' Journal of Engineering and Technology Management 17: 299-319, https://doi.org/10.1016/S0923-4748(00)00027-8.

Schmitter, P. 1979. 'Still the Century of Corporatism?' Pp. 7-52 in Trends towards Corporatism Intermediation, edited by P. Schmitter and G. Lehmbruch. London: Sage.

Siaroff, A. 1999. 'Corporatism in 24 Industrial Democracies: Meaning and Measurement.' European Journal of Political Research 36: 175-205, https://doi.org/10.1111/1475-6765.00467.

Simmie, J., R. Sternberg and J. Carpenter. 2014. 'New Technological Path Creation: Evidence from the British and German Wind Energy Industries.' Journal of Evolutionary Economics 24 (4): 875-904, https://doi.org/10.1007/s00191-014-0354-8.

Sherry, A. et al. 2010. A Review of the UK's Nuclear RED Capability. Swindon: Technology Strategy Board.

Stark, A. 2010. Drawing the Line: Public and Private in America. Washington, DC: Brookings Institution Press.

Steward, T. 2013. 'Demand and Decarbonisation in 2050: Themes from Scenarios.' IGov Working Paper. Energy Policy Group, University of Exeter.

Stone, D. 2013. Knowledge Actors and Transnational Governance: The Private-Public Policy Nexus in the Global Agora. London: Palgrave Macmillan, https://doi.org/10.1057/9781137022912.

Thomas, S. 2004. 'The British Model in Britain: Failing Slowly.' Paper presented at the International Workshop on: 'Thirty Years of World Energy Policy - cum - Editorial Board Meeting of Energy Policy.' Hong Kong Energy Studies Centre. Retrieved 20 November 2018 (http://gala.gre.ac.uk/3757/1/PSIRU_8908_-_2004-04-E-UK-HongKong.pdf).

Van de Donk, W. (eds). 2008. Infrastructures: Time to Invest. Amsterdam: Amsterdam University Press.

Vaughan, A. 2017. 'Foreign Companies Flock to Build Nuclear Plants in the UK." The Guardian, 25 March 2017.

Verbong, G. and D. Loorbach (eds). 2012. Governing the Energy Transition: Reality, Illusion or Necessity? Oxon: Routledge, https:/ / doi.org/10.4324/9780203126523.

Verbruggen, P. and T. Havinga. 2015. 'Introduction to the Special Issue on the Patterns of 
Interplay between Public and Private Regulation.' European Journal of Risk Regulation 6 (4): 482-487, https://doi.org/10.1017/S1867299X00005043.

Weintraub, J. and K. Kumar (eds). 1997. Public and Private in Thought and Practice: Perspectives on a Grand Dichotomy. Chicago, IL: University of Chicago Press.

Wieczorek, A. J., S. O. Negro, R. Harmsen, G. J. Heimeriks, L. Luo and M. P. Hekkert 2013. 'A Review of the European Offshore Wind Innovation System.' Renewable and Sustainable Energy Review 26 (2): 294-306, https://doi.org/10.1016/j.rser.2013.05.045.

Wittmayer, J., F. Avelino, F. van Steenbergen and D. Loorbach. 2017. 'Actor Roles in Transition: Insights from Sociological Perspectives.' Environmental Innovation and Societal Transitions 24: 45-56, https://doi.org/10.1016/j.eist.2016.10.003.

WNN. 2009. 'UK Government Boosts Nuclear Support.' World Nuclear News, 3 December 2009. 